\title{
PENERAPAN STRATEGI PEMBELAJARAN PROBLEM BASED LEARNING UNTUK MENINGKATKAN AKTIVITAS DAN HASIL BELAJAR MATA DIKLAT KEWIRAUSAHAAN SISWA KELAS XI SMK NEGERI 1 LUBUK PAKAM
}

\author{
Windi Prasetya ${ }^{1}$, Asri Lubis ${ }^{2}$ \\ ${ }^{1}$ Alumni Program Studi Pendidikan Teknik Bangunan, Fakultas Teknik UNIMED \\ 2Dosen Pengajar Jurusan Pendidikan Teknik Bangunan, Fakultas Teknik UNIMED \\ (asri2lbs@gmail.com)
}

\begin{abstract}
ABSTRAK
Penelitian ini bertujuan untuk meningkatkan aktivitas dan hasil belajar Kewirausahaan siswa. Jenis penelitian ini adalah Penelitian Tindakan Kelas (PTK). Subjek penelitian adalah siswa kelas XI Program Keahlian Teknik Gambar Bangunan. Teknik pengumpulan data penelitian ini adalah tes dan lembar observasi aktivitas siswa. Pada siklus I diperoleh 9 siswa (30\%) untuk kategori tidak aktif, 5 siswa $(16,67 \%)$ untuk kategori cukup, 10 siswa (33,33\%) untuk kategori aktif dan 6 siswa (20\%) untuk kategori sangat aktif. Siklus II diperoleh 3 siswa (10\%) untuk kategori tidak aktif, 6 siswa (20\%) untuk kategori cukup aktif, 9 siswa untuk kategori aktif (30\%), dan 12 siswa (40\%) untuk kategori sangat aktif. Nilai rata-rata aktivitas belajar siswa pada siklus I yaitu 63 meningkat menjadi 69 pada siklus II. Data nilai hasil belajar siswa pada siklus I diperoleh 9 siswa (30\%) untuk kategori tidak kompeten, 8 siswa (26,67\%) untuk kategori cukup kompeten, 12 siswa (40\%) untuk kategori kompeten dan 1 siswa (3,33\%) untuk kategori sangat kompeten. Siklus II diperoleh 4 siswa (13,33\%) untuk kategori tidak kompeten, 6 siswa (20\%) untuk kategori cukup kompeten, 15 siswa (50\%) untuk kategori kompeten dan 5 siswa (16,67\%). Persentase ketuntasan hasil belajar siswa 70\% pada siklus I dengan perolehan nilai rata-rata 75,33 meningkat menjadi $86,67 \%$ dengan perolehan nilai rata-rata 80,57 pada siklus II. Dapat disimpulkan bahwa dengan menerapkan strategi pembelajaran Problem Based Learning dapat meningkatkan aktivitas dan hasil belajar Kewirausahaan siswa kelas XI Program Keahlian Teknik Gambar Bangunan SMK Negeri 1 Lubuk Pakam.
\end{abstract}

Kata kunci: Pembelajaran Berbasis Masalah, Aktivitas Belajar, Hasil Belajar

\begin{abstract}
This study aims to improve the activity and learning outcomes of students Entrepreneurship. This research is Classroom Action Research (ACR.. The subjects were students of class XI of Skills Program Architecture Engineering. This research data collection techniques are tests and observation of student activity sheet. The data of observations of student activity showed an increase in activity of student learning from the first cycle to the second cycle. The first cycle obtained 9 students (30\%) to the category of inactive, 5 students $(16.67 \%)$ to the category of moderately active, 10 students (33.33\%) for the active category and 6 students $(20 \%)$ to the category of very active. Cycle II gained 3 students (10\%) to the category of inactive, 6 students (20\%) to the category of moderately active, 9 students for active category (30\%), and 12 students (40\%) to the category of very active. Average value of learning activities of students in the first cycle is 63 increased to 69 in the second cycle. Data values of student learning outcomes in the first cycle was obtained 9 students (30\%) to the category of incompetent, 8 students $(26.67 \%)$ for category competent enough, 12 students (40\%) to the category of competent and 1 student (3.33\% ) to the category of very competent. Cycle II obtained 4 students $(13.33 \%)$ to the category of incompetent, 6 students $(20 \%)$ to the category of competent enough, 15 students $(50 \%)$ to the category of competent and 5 students $(16.67 \%)$. percentage of completeness of student learning outcomes by $70 \%$ in the first cycle with the acquisition of
\end{abstract}


an average value of 75.33 increased to $86.67 \%$ with an average acquisition value of 80.57 in the second cycle. It can be concluded that by applying the Problem Based Learning learning strategies can increase the activity and learning outcomes of students of class XI Enterprise Architecture Engineering Expertise Program SMK 1 Lubukpakam.

\section{Keywords: Problem Based Learning, Learning Activity, Learning Outcomes}

\section{Pendahuluan}

Kewirausahaan merupakan salah satu mata pelajaran yang penting di SMK khususnya di Kelas XI Program Keahlian Teknik Gambar Bangunan SMK Negeri 1 Lubuk Pakam dan juga sangat bermanfaat buat lulusan siswa SMK untuk mengembangkan potensi berwirausaha sesuai dengan bidang dan keahlian lulusan siswa SMK nantinya. Seiring dengan visi dan misi Direktorat Pendidikan Menengah Kejuruan maka SMK diharapkan mampu menurunkan tingkat pengangguran dengan tujuan untuk menghasilkan lulusan yang siap kerja dan membangun jiwa wirausaha, maka peranan SMK menjadi sangat dibutuhkan di tengah masyarakat. Oleh karena itu sangat memerlukan pemahaman dan latihan di dalam mempelajari Kewirausahaan. Sehingga dalam penyampaiannya guru harus mampu merancang, mengelola dan mengevaluasi pembelajaran dengan baik yang akhirnya terlihat pada kemampuan siswa untuk meningkatkan aktivitas dan hasil belajar.

Berdasarkan hasil observasi awal yang penulis lakukan, bahwa hasil belajar Kewirausahaan pada siswa kelas XI Program Keahlian Teknik Gambar Bangunan SMK Negeri 1 Lubuk Pakam masih kurang sesuai dengan yang diharapkan, hal ini dilihat dari nilai hasil belajar ulangan akhir semester Kewirausahaan siswa kelas XI Program Keahlian Teknik Gambar Bangunan, seperti pada tabel di bawah ini :

Tabel 1 Perolehan Hasil Belajar Ulangan Akhir Semester Kewirausahaan Kelas XI Program Keahlian Teknik Gambar Bangunan SMK Negeri 1 Lubuk Pakam

\begin{tabular}{|c|c|l|c|l|}
\hline $\begin{array}{c}\text { Tahun } \\
\text { Pelajaran }\end{array}$ & KKM & $\begin{array}{c}\text { Interval } \\
\text { Kelas }\end{array}$ & $\begin{array}{c}\text { Frekuensi } \\
\text { Absolut } \\
(\text { Fo })\end{array}$ & $\begin{array}{c}\text { Frekuensi } \\
\text { Relatif } \\
(\mathrm{Fr})\end{array}$ \\
\hline & & $0-69$ & 14 & $41,18 \%$ \\
$2011 /$ & 70 & $70-79$ & 12 & $35,29 \%$ \\
2012 & & $80-89$ & 8 & $23,53 \%$ \\
& $90-100$ & - & - \\
\hline & & $0-69$ & 17 & $47,22 \%$ \\
$2012 /$ & 70 & $70-79$ & 11 & $30,55 \%$ \\
2013 & & $80-89$ & 5 & $13,89 \%$ \\
& & $90-100$ & 3 & $8,33 \%$ \\
\hline & & $0-69$ & 16 & $53,33 \%$ \\
2013 & 70 & $70-79$ & 9 & $30,00 \%$ \\
\hline 2014 & & $80-89$ & 4 & $13,33 \%$ \\
\hline
\end{tabular}

Sumber: Guru Mata diklat Kewirausahaan Kelas XI SMKN 1 Lubuk Pakam
Berdasarkan perbandingan nilai tersebut maka penulis menyatakan pencapaian nilai pada mata pelajaran Kewirausahaan masih rendah dan belum tercapai dengan sempurna. Rendahnya hasil belajar Kewirausaan bisa disebabkan oleh beberapa faktor yang meliputi siswa, guru, metode atau strategi pembelajaran yang saling berhubungan satu sama lain.

Pembelajaran Kewirausahaan yang berlangsung di sekolah saat ini masih ada yang menerapkan strategi pembelajaran dengan metode ceramah, yaitu sistem yang bertumpu pada aktivitas guru. Proses pembelajaran seperti inilah yang menimbulkan kurang berkembangnya sikap kemandirian belajar pada siswa saat belajar Kewirausahaan. Tanpa guru, siswa merasa tidak dapat belajar dan tidak perlu belajar secara teratur. Siswa akan belajar manakala ada guru yang memberikan materi pembelajaran kewirausahaan melalui ceramah, sehingga siswa merasa ada guru yang berceramah berarti ada proses belajar dan tidak ada guru berarti tidak belajar. Hal ini didukung oleh Slameto (2010: 65 ) yang mengatakan bahwa "guru biasa mengajar dengan metode ceramah saja, siswa menjadi bosan, mengantuk, pasif, dan hanya mencatat saja.

Untuk mengatasi masalah di atas, maka dilakukan pemilihan strategi pembelajaran yang lebih baik dan menyenangkan yang dapat meningkatkan aktivitas dan hasil belajar siswa. Salah satu alternatif yang dapat digunakan yaitu menerapkan strategi pembelajaran berdasarkan Problem Based Learning (PBL) yang diharapkan dapat memberikan ruang seluas-luasnya kepada siswa untuk berpikir dan terlibat secara aktif serta kreatif dalam suatu pembelajaran.

Dengan menggunakan strategi pembelajaran Problem Based Learning akan menciptakan suasana belajar yang menyenangkan, bermakna dan menyeluruh. Sebab, selain memberikan ruang yang seluas-luasnya bagi siswa untuk berpikir kritis dan ikut langsung mendalami permasalahan yang timbul dalam pembelajaran, siswa juga diajak untuk menyelesaikan masalah yang timbul dan mempertanggung jawabkan 


\section{Penerapan Strategi Pembelajaran Problem Based Learning Untuk Meningkatkan Aktivitas dan Hasil Belajar Mata Diklat Kewirausahaan Siswa Kelas XI SMK Negeri 1 Lubuk Pakam}

penyelesaiannya serta dapat menggunakan pengetahuan yang diperolehnya dalam situasi dan kondisi yang berbeda. Guru pada pembelajaran ini berperan sebagai fasilitator dan mediator dalam pembentukan pemahaman siswa. Siswa yang lebih memegang peranan dalam pembelajaran.

Berdasarkan uraian di atas maka penulis tertarik untuk mengadakan Penelitian Tindakan Kelas (PTK) dengan judul "Penerapan Strategi Pembelajaran Problem Based Learning Untuk Meningkatkan Aktivitas dan Hasil Belajar Mata Diklat Kewirausahaan Siswa Kelas XI Program Keahlian Teknik Gambar Bangunan SMK Negeri 1 Lubuk Pakam".

\section{Kerangka Teoritis}

\subsection{Hakikat Strategi Pembelajaran Problem Based Learning (PBL)}

Problem Based Learning adalah suatu strategi pembelajaran yang dipilih dari permasalahanpermasalahan yang nyata di dalam kehidupan sehari-hari. Strategi ini melatih siswa untuk berpikir aktif dan bekerjasama di dalam kelompok belajarnya, dan pada strategi ini siswa dituntut mampu mengembangkan ide dan gagasan sehingga dapat dicari solusi untuk menyelesaikan masalah yang telah ditemukan.

Adapun langkah-langkah Strategi pembelajaran Problem Based Learning, yaitu :

\section{Tabel 2 Langkah-langkah Problem Based Learning}

\begin{tabular}{|c|l|lr|}
\hline Fase & \multicolumn{1}{|c|}{ Indikator } & \multicolumn{2}{|c|}{ Tingkah Laku Guru } \\
\hline 1 & $\begin{array}{l}\text { Orientasi } \\
\text { siswa pada } \\
\text { masalah }\end{array}$ & $\begin{array}{l}\text { Menjelaskan tujuan } \\
\text { pembelajaran, menjelaskan } \\
\text { logistik yang diperlukan, } \\
\text { dan memotivasi siswa } \\
\text { terlibat pada aktivitas } \\
\text { pemecahan masalah }\end{array}$ \\
\hline 2 & $\begin{array}{l}\text { Mengorganis } \\
\text { asi siswa } \\
\text { untuk belajar }\end{array}$ & $\begin{array}{l}\text { Membantu diswa } \\
\text { mendefinisikan dan } \\
\text { mengorganisasikan tugas } \\
\text { belajar yang berhubungan } \\
\text { dengan masalah tersebut. }\end{array}$ \\
\hline 3 & $\begin{array}{l}\text { Membimbing } \\
\text { pengalaman } \\
\text { individual/ } \\
\text { kelompok }\end{array}$ & $\begin{array}{l}\text { Mendorong siswa untuk } \\
\text { mengumpulkan informasi } \\
\text { yang sesuai, melaksanakan } \\
\text { eksperimen untuk } \\
\text { mendapat penjelasan dan } \\
\text { pemecahan masalah. }\end{array}$ \\
\hline 4 & Mengembang & Membantu siswa dalam \\
\hline
\end{tabular}

\begin{tabular}{|c|l|l|}
\hline Fase & \multicolumn{1}{|c|}{ Indikator } & \multicolumn{2}{|c|}{ Tingkah Laku Guru } \\
\hline & $\begin{array}{l}\text { kan dan } \\
\text { menyajikan } \\
\text { hasil karya }\end{array}$ & $\begin{array}{l}\text { merencanakan dan } \\
\text { menyiapkan karya yang } \\
\text { sesuai seperti laporan, dan } \\
\text { membantu mereka untuk } \\
\text { berbagi tuga dengan } \\
\text { temannya. }\end{array}$ \\
\hline 5 & $\begin{array}{l}\text { Menganalisis } \\
\text { dan } \\
\text { mengevaluasi } \\
\text { proses } \\
\text { pemecahan } \\
\text { masalah }\end{array}$ & $\begin{array}{l}\text { Membantu siswa untuk } \\
\text { melakukan refleksi atau } \\
\text { evaluasi terhadap } \\
\text { penyelidikan mereka dan } \\
\text { proses yang mereka } \\
\text { gunakan. }\end{array}$ \\
\hline
\end{tabular}

Sumber: Ibrahim, dkk. dalam Rusman (2011:243)

Berdasarkan uraian di atas, dapat disimpulkan langkah-langkah strategi pembelajaran Problem Based Learning adalah fokus pada pendesainan masalah, menganalisis dan mengumpukan informasi, dan merencanakan serangkaian aktivitas yang dapat melibatkan siswa secara aktif, menyajikan laporan hasil karya dan akhirnya akan dievaluasi oleh guru.

\subsection{Hakikat Aktivitas Belajar}

Aktivitas belajar siswa adalah keterlibatan siswa dalam bentuk sikap, pikiran, perhatian. Peningkatan aktivitas siswa yaitu meningkatnya jumlah siswa yang terlibat aktif dalam belajar, meningkatnya jumlah siswa yang bertanya dan menjawab, meningkatnya jumlah siswa yang saling berinteraksi membahas materi pembelajaran.

\subsection{Hakikat Hasil Belajar Kewirausahaan}

Hasil belajar menggambarkan kemampuan yang dimiliki siswa baik dalam aspek afektif, kognitif, dan psikomotorik. Siskandar (2009: 179) mengatakan bahwa "Hasil belajar diaplikasikan dalam bentuk prilaku dan perubahan pribadi setelah proses pembelajaran berlangsung". Sedangkan Djamarah (2008: 119) menyimpulkan bahwa "Hasil belajar adalah kemampuan yang diperoleh siswa setelah melalui kegiatan belajar".

Dalam mata pelajaran Kewirausahaan tujuan pembelajaran ada tiga ranah yaitu kognitif, afektif dan psikomotorik. Pada ranah kognitif, siswa harus dapat memahami materi, mengingat kembali, menerapkan, menganalisis dan melakukan sintesis terhadap soal yang diberikan guru, di mana siswa harus mampu menerapkan pengetahuan dan kemampuan untuk 
menyelesaikan soal yang diberikan oleh guru. Pada rana afektif mengenai sikap, siswa merespon pertanyaan yang diberikan oleh guru sesuai dengan pendapat pribadinya. Kemudian pada ranah psikomotorik, akan berhubungan langsung dengan keterampilan dan kemampuan siswa.

Dari uraian di atas maka dapat disimpulkan bahwa hasil belajar adalah perubahan tingkah laku yang mencakup bidang kognitif, afektif, dan psikomotorik yang diperoleh peserta didik setelah mengikuti kegiatan pembelajaran. Proses pembelajaran dan hasil belajar merupakan dua hal yang tidak dapat dipisahkan, maka segala sesuatu yang mempengaruhi proses pembelajaran harus dioptimalkan agar mencapai hasil belajar yang lebih baik.

\subsection{Pengajuan Hipotesis}

a. Penerapan strategi pembelajaran Problem Based Learning diduga dapat meningkatkan aktivitas belajar Kewirausahaan siswa kelas XI Program Keahlian Teknik Gambar Bangunan di SMK Negeri 1 Lubuk Pakam 2014/2015.

b. Penerapan strategi pembelajaran Problem Based Learning diduga dapat meningkatkan hasil belajar Kewirausahaan siswa kelas XI Program Keahlian Teknik Gambar Bangunan di SMK Negeri 1 Lubuk Pakam 2014/2015.

\section{Metodologi Penelitian}

Penelitian ini dilaksanakan di SMK Negeri 1 Lubuk Pakam kelas xi Program Keahlian Teknik Gambar Bangunan tahun ajaran 2014/2015 untuk mata diklat Kewirausahaan. Waktu penelitian dilaksanakan pada semester genap pada bulan Januari 2015 sampai dengan selesai.

Subjek dalam penelitian ini adalah siswa kelas XI Program Keahlian Teknik Gambar Bangunan SMK Negeri 1 Lubuk Pakam tahun ajaran 2014/2015 dengan jumlah 30 orang. Objek dalam penelitian ini adalah meningkatkan aktivitas dan hasil belajar siswa dengan menggunakan Strategi Pembelajaran Problem Based Learning pada materi pokok peluang usaha di kelas $X$ Program Keahlian Teknik Gambar Bangunan SMK Negeri 1 Lubuk Pakam tahun ajaran 2014/2015.

Penelitian yang dilakukan ini adalah penelitian tindakan kelas (classroom action research). Penelitian tindakan kelas digunakan dalam rangka pengumpulan data untuk perbaikan dan peningkatan pengetahuan mengenai aktivitas dan hasil belajar Kewirausahaan. Penelitian ini dilakukan dalam dua siklus atau lebih dan tiap siklusnya terdiri dari empat tahap (Arikunto, 2009:16) yaitu 1.Perencanaan, 2.Tindakan, 3.Pengamatan, 4.Refleksi.

Adapun model untuk masing-masing tahapan digambarkan sebagai berikut:

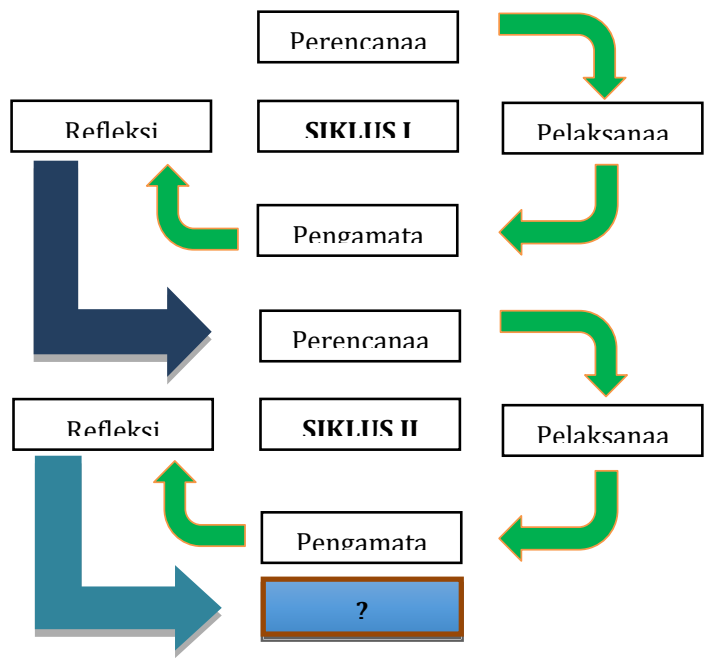

\section{Gambar 1 Skema Penelitian Tindakan Kelas}

Langkah-langkah yang akan dilakukan dalam proses penelitian tindakan ini adalah :

1) Melakukan observasi lingkungan sekolah, guru yang sedang mengajar dan siswa yang menjadi objek penelitian.

2) Melakukan diskusi dengan PKS I dan bekerjasama dengan guru mata pelajaran Kewirausahaan untuk menganalisis kurikulum tentang penerapan strategi pembelajaran Problem Based Learning dalam belajar.

3) Melakukan proses pembelajaran dengan menggunakan strategi pembelajaran Problem Based Learning, di mana aktivitas belajar siswa diamati pada saat pembelajaran berlangsung, dengan menjelaskan terlebih dahulu cara kerja strategi pembelajaran Problem Based Learning kepada siswa.

4) Setelah proses pembelajaran dengan menggunakan strategi pembelajaran Problem Based Learning selesai maka siswa diberikan tes dengan tujuan untuk mengetahui apakah hasil belajar siswa mengalami peningkatan.

5) Melakukan refleksi dengan melihat hasil tes belajar siswa yang dijadikan sebagai dasar untuk melaksanakan siklus berikutnya. 


\section{Penerapan Strategi Pembelajaran Problem Based Learning Untuk Meningkatkan Aktivitas dan Hasil Belajar Mata Diklat Kewirausahaan Siswa Kelas XI SMK Negeri 1 Lubuk Pakam}

Teknik dan analisis pengumpulan data yang digunakan adalah lembar observasi aktivitas belajar siswa dan tes hasil belajar.Observasi dilakukan untuk mengetahui aktivitas siswa selama proses pembelajaran.

Adapun aspek aktivitas yang dinilai, yang dianggap perlu pada mata pelajaran Kewirausahaan adalah sebagai berikut:

1. Visual activities (memperhatikan pembelajaran).

2. Oral activities (mengajukan pertanyaan).

3. Listening activities (mendengar diskusi).

4. Mental activities (memberikan pendapat).

5. Emotional Activities (menaruh minat pada pembelajaran).

Keterangan dari perolehan skor tiap-tiap aspek yang dinilai yang dikemukakan oleh Aqib (2009: 67) sebagai berikut :

1 = tidak pernah melakukan

2 = dilakukan namun jarang

3 = sering dilakukan

4 = sangat sering dilakukan

Untuk menentukan total skor dan kategori penilaian yang diperoleh siswa digunakan rumus yang dikemukakan Sudijono; dalam Rosmaini dkk (2004) sebagai berikut :
Nilai $=\frac{\text { Nilai yang diperole } h \text { siswa }}{\text { Jumla } h \text { Nilai Max }} \times 100$

Kategori Penilaian:

$0-54=$ Tidak aktif

$55-64=$ Cukup aktif

$65-74=$ Aktif

$75-100=$ Sangat aktif

Tes menggunakan bentuk pilihan berganda, yang terdiri dari 4 pilihan. Setiap pilihan mempunyai 1 jawaban benar dan 3 pengecoh. Setiap butir soal yang dijawab benar diberi nilai 1 dan untuk jawaban yang salah diberi nilai 0 . Adapun jumlah soal pilihan berganda sebanyak 72 soal, di mana 37 soal untuk siklus pertama dan 35 soal untuk siklus kedua yang sudah diuji validitasnya dari 80 soal kepada siswa kelas XII SMK Negeri 1 Lubuk Pakam karena sudah menerima pelajaran Kewirausahaan pada materi pokok peluang usaha. Tes dilaksanakan untuk melihat hasil belajar siswa setelah pelaksanaan tindakan pada kompetensi yang ditetapkan pada siswa kelas XI.

Secara lebih detail distribusi instrumen tes dapat dilihat dalam kisi-kisi instrumen pada tabel 3 dan 4 berikut ini.

Tabel 3 Kisi - Kisi Instrumen Kewirausahaan Siklus I

\begin{tabular}{|c|c|c|c|c|c|}
\hline \multirow{2}{*}{ NO } & \multirow{2}{*}{ INDIKATOR } & \multicolumn{3}{|c|}{ NOMOR ITEM } & \multirow{2}{*}{ JUMLAH } \\
\hline & & $\mathrm{C}_{1}$ & $\mathrm{C}_{2}$ & $\mathrm{C}_{3}$ & \\
\hline 1 & Menjelaskan peluang dan resiko usaha & $1,3,4,9,11$ & $2,8,10$ & $5,6,7$ & 11 \\
\hline 2 & $\begin{array}{l}\text { Menjelaskan faktor-faktor keberhasilan } \\
\text { dan kegagalan usaha }\end{array}$ & $\begin{array}{l}17,18, \\
19,22,25\end{array}$ & $\begin{array}{l}12,15,16 \\
20,21,26\end{array}$ & $\begin{array}{l}13,14 \\
23,24\end{array}$ & 15 \\
\hline 3 & $\begin{array}{l}\text { Menjelaskan tentang mengembangkan ide } \\
\text { dan peluang usaha }\end{array}$ & $\begin{array}{l}27,33 \\
35,37\end{array}$ & $\begin{array}{l}28,29,30 \\
32,36\end{array}$ & 31,34 & 11 \\
\hline & Jumlah & 14 & 14 & 9 & 37 \\
\hline \multicolumn{6}{|c|}{ Total } \\
\hline
\end{tabular}


Tabel 4 Kisi - Kisi Instrumen Kewirausahaan Siklus II

\begin{tabular}{|c|c|c|c|c|c|}
\hline \multirow{2}{*}{ NO } & \multirow{2}{*}{ INDIKATOR } & \multicolumn{3}{|c|}{ NOMOR ITEM } & \multirow{2}{*}{ JUMLAH } \\
\hline & & $\mathrm{C}_{1}$ & $\mathrm{C}_{2}$ & $\mathrm{C}_{3}$ & \\
\hline 1 & $\begin{array}{l}\text { Menjelaskan mengenai menganalisis } \\
\text { kemungkinan keberhasilan dan kegagalan } \\
\text { usaha }\end{array}$ & $\begin{array}{l}4,6,9 \\
16,17\end{array}$ & $\begin{array}{l}5,11,12,13, \\
14,35\end{array}$ & $\begin{array}{l}7,8,10 \\
15,18\end{array}$ & 16 \\
\hline 2 & Menjelaskan memetakan peluang usaha & $19,26,34$ & $20,23,25$ & $21,22,24$ & 9 \\
\hline 3 & $\begin{array}{l}\text { Menjelaskan pemanfaatan peluang secara } \\
\text { kreatif dan inovatif }\end{array}$ & $1,27,28,31$ & $2,29,32$ & $3,30,33$ & 10 \\
\hline & 12 & 12 & 11 & 35 \\
\hline
\end{tabular}

Keterangan :

$\begin{array}{ll}\mathrm{C}_{1} & : \text { Pengetahuan } \\ \mathrm{C}_{2} & : \text { Pemahaman } \\ \mathrm{C}_{3} & : \text { Aplikasi }\end{array}$

Kesukaran butir soal diperoleh dari 37 soal yang valid pada siklus I yang disusun terdapat 37 butir soal kategori sedang. Pada siklus II dari 35 soal yang valid terdapat 31 butir soal kategori sedang dan 4 soal kategori mudah Dengan tingkat reliabilitas sangat tinggi dengan nilai pada instrumen siklus I sebesar 0,812 dan pada siklus II sebesar 0,918.

Dari 37 butir soal yang valid untuk siklus I terdapat 15 butir soal dengan pembeda baik, 20 butir soal dengan pembeda cukup dan 2 butir soal dengan pembeda jelek. Pada siklus II dari 35 soal yang valid terdapat 15 butir soal dengan pembeda baik dan 20 butir soal dengan pembeda cukup.

Kemudian untuk mengetahui persentase peningkatan aktivitas belajar siswa dapat dihitung dengan menggunakan rumus :

$\%$ Aktivitas siswa $=\frac{\text { Jumla } h \text { siswa yang aktif }}{\text { Jumla } h \text { seluru } h \text { siswa }} \times 100 \%$

Hasil belajar siswa dianalisis dengan melihat ketuntasan belajar siswa. Setelah nilai ketuntasan belajar diperoleh, penetapan skor nilai ketuntasan hasil belajar siswa dalam penelitian ini menggunakan rumus sebagai berikut:

\section{a. Ketuntasan Individual}

DS $=\frac{\text { Skor Yang Diperoleh Siswa }}{\text { Skor Maksimal }} \times 100$

Dengan Kriteria:

$<70 \quad=$ Tidak Kompoten

$70-79$ = Cukup Kompoten
$80-89=$ Kompoten

$90-100=$ Sangat Kompoten

b. Ketuntasan Klasikal

Persentase siswa yang telah tuntas belajar secara klasikal dapat diketahui dengan rumus:

$D=\frac{X}{N} \times 100 \%$

(Arikunto, 2009)

Keterangan:

$\mathrm{D}=$ Persentase Ketuntasan Belajar Klasikal

$\mathrm{X}=$ Jumlah siswa yang telah tuntas belajar

$\mathrm{N}=$ Jumlah seluruh siswa

\section{Hasil Dan Pembahasan Penelitian}

Penelitian ini dilaksanakan dalam dua siklus di mana siklus pertama dilaksanakan pada tanggal 24 dan 31 Januari 2015 dan siklus kedua dilaksanakan pada tanggal 7 dan 14 Februari 2015. Adapun langkah-langkah yang dilakukan dalam penelitian akan diuraikan sebagai berikut :

\section{a. Pelaksanaan Siklus I}

\section{Tahap Perencanaan (Planning)}

AdapukAqj3k2909) pembahasan dalam siklus I adalah peluang dan resiko usaha, faktor-faktor keberhasilan dan kegagalan peluang usaha, dan mengembangkan ide dan peluang usaha. Dalam tahap ini peneliti mendiskusikan dengan guru mengenai silabus, RPP, materi pembelajaran dan langkah-langkah dalam penerapan strategi pembelajaran Problem Based Learning.

\section{Tahap Pelaksanaan (Action)}

Dalam(AscikiuptosiROQ9) dilaksanakan dengan durasi waktu $4 \times 45$ menit (2 kali pertemuan). Pada pertemuan pertama siklus ini diawali dengan materi pokok peluang dan resiko usaha serta faktor-faktor keberhasilan dan kegagalan peluang usaha. Sebelum memulai tahap 


\section{Penerapan Strategi Pembelajaran Problem Based Learning Untuk Meningkatkan Aktivitas dan Hasil Belajar Mata Diklat Kewirausahaan Siswa Kelas XI SMK Negeri 1 Lubuk Pakam}

pelaksanaan, guru memberikan tes pilihan berganda (pre test) untuk mengetahui kemampaun awal siswa. Pembelajaran diawali dengan berdoa bersama kemudian guru mendata kehadiran siswa. Setelah itu guru menjelaskan gambaran singkat tentang materi pelajaran dan memberi motivasi kepada siswa agar bersemangat dalam mengikuti pembelajaran. Guru juga menjelaskan pelaksanaan pembelajaran melalui penerapan strategi pembelajaran Problem Based Learning.

Dalam proses pembelajaran guru menjelaskan, mengajukan pertanyaan dan memberikan permasalahan yang mengarahkan kemateri pelajaran yang diangkat dari kehidupan sehari-hari ataupun lingkungan sekitar siswa. Guru membimbing siswa untuk menggunakan kemampuan awal untuk memahami, memberikan respon dan pendapat mengenai permasalahan sesuai materi pelajaran. Kemudian guru membagi seluruh siswa yang berjumlah 30 siswa menjadi 6 kelompok berdasarkan absen kelas, di mana setiap kelompok terdiri dari 5 siswa. Guru memberikan tugas dan membimbing kelompok untuk mengumpulkan fakta, mencari informasi dan mengelola informasi. Kemudian guru membimbing siswa dan tiap-tiap kelompok berdiskusi dalam mengembangkan pembahasan masing-masing kelompok. Masing-masing kelompok menyiapkan laporan yang kemudian digunakan untuk dipresentasikan. Setiap kelompok menyampaikan dan mempresentasikan hasil diskusi dalam pemecahan masalah kepada kelompok lain serta memberikan kesimpulan. Setelah proses presentasi antar kelompok selesai, guru merangkum materi pembelajaran dan memberikan kesempatan kepada siswa untuk membuat kesimpulan berdasarkan materi yang diajarkan. Kemudian guru menanyakan kesulitan yang dialami siswa selama proses pembelajaran. Sebagai penutup guru memberikan salam kepada siswa.

Pada pertemuan kedua diawali dengan peneliti sekilas mengulang kembali pelajaran pada pertemuan pertama dan melakukan tanya jawab tentang materi yang lalu. Kemudian dilanjutkan kegiatan atau tahapan seperti pada pertemuan pertama dengan materi pokok mengembangkan ide dan peluang usaha. Pada pertemuan kedua ini siswa sudah mulai mengerti tentang bagaimana pembelajaran Problem Based Learning. Siswa mulai siap untuk maju ke depan kelas jika kelompoknya disebut, selanjutnya siswa mulai lebih aktif untuk memberikan tanggapan-tanggapan mereka.

Pada akhir siklus pertama dilakukan posttes untuk melihat peningkatan aktivitas dan hasil belajar siswa setelah dilakukannya proses pebelajaran dengan menggunakan strategi pembelajaran Problem Based Learning. Dari hasil pengamatan peneliti dan dibantu dengan guru dapat disimpulkan bahwa pelaksanaan belum sesuai dengan rencana. Hal ini disebabkan oleh :

1) Sebagian siswa belum terbiasa dengan kondisi belajar menggunakan strategi pembelajaran Problem Based Learning.

2) Sebagian siswa belum memahami langkahlangkah pembelajaran strategi pembelajaran Problem Based Learning secara utuh dan menyeluruh.

3) Pada saat pemberian pre tes nilai siswa masih tergolong rendah, hal ini diakibatkan karena kurang nya pengetahuan awal siswa tentang materi peluang usaha.

4) Ketika pembelajaran diterapkan, terjadi keributan kecil karena siswa belum terkontrol.

Untuk mengatasi masalah di atas dilakukan upaya sebagai berikut :

1) Guru mata pelajaran Kewirausahaan dengan intensif memberi pengertian kepada siswa kondisi dalam belajar dengan strategi pembelajaran Problem Based Learning.

2) Guru membantu siswa yang belum memahami langkah-langkah pembelajaran dengan strategi pembelajaran Problem Based Learning.

3) Guru mencoba membangkitkan kembali ingatan siswa tentang materi peluang usaha yang berhubungan dengan kehidupan seharihari siswa.

Tahap Pengamatan (Observation)

Kegiatan pengamatan (observasi) dilakukan untuk melihat keaktifan siswa selama penerapan strategi pembelajaran Problem Based Learning dalam proses pembelajaran dengan menggunakan lembar observasi. Observasi dilakukan setiap pertemuan dan diakumulasikan setiap siklusnya untuk disederhanakan menjadi 
data yang lebih spesifik, yaitu : tidak aktif, cukup, aktif dan sangat aktif.

Berikut ini dijelaskan aktivitas siswa selama proses pembelajaran berlangsung

Tabel 5 Perolehan Nilai Aktivitas Belajar Siswa pada Siklus I

\begin{tabular}{|c|c|c|c|c|}
\hline No. & Interval Kelas & Frekuensi Absolut (Fo) & Frekuensi Relatif (Fr) & Keterangan \\
\hline 1. & $75-100$ & 6 & $20 \%$ & Sangat Aktif \\
\hline 2. & $65-74$ & 10 & $33,33 \%$ & Aktif \\
\hline 3. & $55-64$ & 5 & $16,67 \%$ & Cukup Aktif \\
\hline 4. & $0-54$ & 9 & $30 \%$ & Tidak Aktif \\
\hline \multicolumn{2}{r|}{ Total } & $\mathbf{3 0}$ & $\mathbf{1 0 0} \%$ & \\
\hline
\end{tabular}

Dari data hasil observasi terhadap aktivitas siswa terdapat lima aspek yang dinilai kepada 30 siswa, di mana siswa yang memperoleh kategori tidak aktif sebanyak 9 siswa $(30 \%)$, kategori cukup aktif 5 siswa $(16,67 \%)$, kategori aktif 10 siswa $(33,33 \%)$ dan untuk kategori sangat aktif 6 siswa (20\%). Sesuai dengan data tersebut maka aktivitas siswa dikatakan belum berhasil, di mana masih banyaknya jumlah siswa dalam kategori tidak aktif dan rata-rata perolehan nilai aktivitas masih sebesar 63 masuk dalam kategori cukup.

Tahap selanjutnya adalah mengamati hasil belajar siswa melalui tes pilihan berganda yang dilakukan setelah proses tindakan selesai. Hal ini dilakukan untuk mengetahui penerapan strategi pembelajaran Problem Based Learning dapat meningkatkan hasil belajar siswa serta melakukan refleksi terhadap proses pembelajaran agar aktivitas dan hasil belajar siswa dapat meningkat.

Setelah proses pembelajaran selesai dilakukan maka dilakukan perhitungan terhadap hasil belajar yang diperoleh siswa. Pembagian kelompok yang tidak merata berdampak pada hasil belajar siswa yang belum memuaskan. Untuk perolehan hasil belajar siswa disajikan pada tabel berikut Ini :

Tabel 6 Perolehan Nilai Hasil Belajar Siswa pada Siklus I

\begin{tabular}{|c|c|c|c|c|}
\hline No. & Interval Kelas & Frekuensi Absolut (Fo) & Frekuensi Relatif (Fr) & Keterangan \\
\hline 1. & $90-100$ & 1 & $3,33 \%$ & Sangat Kompeten \\
\hline 2. & $80-89$ & 12 & $40 \%$ & Kompeten \\
\hline 3. & $70-79$ & 8 & $26,67 \%$ & Cukup Kompeten \\
\hline 4. & $0-69$ & 9 & $30 \%$ & Tidak Kompeten \\
\hline \multicolumn{2}{r|}{ Total } & $\mathbf{3 0}$ & $\mathbf{1 0 0} \%$ & \\
\hline
\end{tabular}

Dari hasil belajar yang diperoleh siswa pada waktu pelaksanaan tindakan selesai maka diketahui nilai hasil belajar siswa dengan kategori tidak kompeten sebanyak 9 siswa(30\%), kategori cukup kompeten 8 siswa $(26,67 \%)$, kategori kompeten 12 siswa (40\%), sedangkan kategori sangat kompeten dicapai oleh 1 siswa saja $(3,33 \%)$.

Sesuai dengan data di atas maka hasil belajar siswa dapat dikatakan belum berhasil karena jumlah siswa yang masuk dalam kategori tidak kompeten masih tergolong tinggi dan belum tercapainya persentase belajar klasikal ( $\geq 85 \%$ ) yaitu masih $70 \%$ untuk persentase siswa yang tuntas belajar dengan perolehan nilai ratarata 75,33. Sehingga perlu dilanjut ke siklus II untuk meningkatkan aktivitas dan hasil belajar siswa dengan memperhatikan kelemahan yang terjadi selama pelaksanaan proses pembelajaran siklus I.

Tahap Refleksi (Reflection) 


\section{Penerapan Strategi Pembelajaran Problem Based Learning Untuk Meningkatkan Aktivitas dan Hasil Belajar Mata Diklat Kewirausahaan Siswa Kelas XI SMK Negeri 1 Lubuk Pakam}

Berdasarkan data pengamatan di atas ditemukan kelemahan yang terjadi pada siklus I yaitu :

Secara umum guru melaksanakan proses pembelajaran sesuai dengan strategi pembelajaran Problem Based Learning. Akan tetapi terdapat kelemahan dalam langkah kedua di mana guru membagi kelompok berdasarkan absen kelas. Hal ini menyebabkan pembagian anggota kelompok tidak merata. Ada kelompok yang beranggotakan secara keseluruhan siswa yang berkemampuan tinggi, ada kelompok yang beranggotakan siswa yang berkemampuan sedang dan kurang. Ketidakseimbangan dalam pembagian kelompok ini menyebabkan ada siswa yang tidak aktif dalam diskusi kelompok. Siswa yang berkemampuan kurang beranggapan bahwa siswa yang berkemampuan tinggi dan sedang saja yang boleh aktif dalam kelompok karena mereka lebih memahami pokok pembahasan. Hal ini juga berdampak pada hasil belajar siswa (post test I) yang terlihat belum memuaskan, di mana jumlah siswa yang masuk dalam kategori tidak tuntas masih tinggi.

Dalam membagi anggota kelompok, guru seharusnya menggelompokkan siswa secara heterogen agar pembagian siswa yang berkemampuan tinggi, sedang dan kurang, tercampur sehingga adanya pemerataan dalam setiap kelompok. Oleh karena itu perlu dilaksanakan siklus II untuk memperbaiki kelemahan yang terjadi pada siklus I.

\section{b. Pelaksanaan Siklus II}

\section{Tahap Perencanaan (Planning)}

Sesuai dengan hasil refleksi pada siklus I, diketahui bahwa hasil belum memuaskan baik dari aktivitas maupun hasil belajar. Hal ini disebabkan karena kelemahan yang terjadi yaitu pembagian kelompok yang tidak dilakukan secara heterogen. Oleh karena itu perlu dilakukan siklus II untuk memperbaiki kelemahan tersebut dalam meningkatkan hasil aktivitas dan hasil belajar.

Guru dan peneliti mendiskusikan kelemahan yang perlu diperbaiki dari siklus sebelumnya. Silabus, RPP, materi pembelajaran dan langkahlangkah dalam penerapan strategi pembelajaran Problem Based Learning perlu didiskusikan kembali sebagai pemantapan dalam mempersiapkan proses pembelajaran pada siklus ini.

\section{Tahap Pelaksanaan (Action)}

Dalam proses pembelajaran kali ini, sesuai dengan refleksi dari siklus I guru menata kembali pembagian kelompok secara heterogen agar terjadinya pemerataan dalam setiap kelompok yaitu terdiri dari siswa yang berkemampuan tinggi, sedang dan kurang. Dalam pelaksanaan tindakan pada siklus kedua, berlangsung dalam durasi waktu $4 \times 45$ menit $(2$ $x$ pertemuan) dengan materi menganalisis kemungkinan keberhasilan dan kegagalan serta memetakan peluang usaha. Dan pada pertemuan kedua pada siklus kedua dengan materi pemanfaatan peluang secara kreatif dan inovatif.

Setelah proses pembelajaran selesai, guru melakukan evaluasi belajar dengan memberikan tes pilihan berganda (post test). Setelah evaluasi guru menanyakan kembali kesulitan yang dialami siswa selama proses pembelajaran. Sebagai penutup guru memberikan salam kepada siswa.

\section{Tahap Pengamatan (Observation)}

Selama proses pembelajaran, semakin banyak siswa yang berperan aktif dalam diskusi antar kelompok, dan semakin banyak siswa yang memberikan pendapat dalam diskusi. Berikut ini dijelaskan peningkatan aktivitas siswa selama proses pembelajaran berlangsung.

Tabel 7 Perolehan Nilai Aktivitas Belajar Siswa pada Siklus II

\begin{tabular}{|c|c|c|c|c|}
\hline No. & Interval Kelas & Frekuensi Absolut (Fo) & Frekuensi Relatif (Fr) & Keterangan \\
\hline 1. & $75-100$ & 12 & $40 \%$ & Sangat Aktif \\
\hline 2. & $65-74$ & 9 & $30 \%$ & Aktif \\
\hline 3. & $55-64$ & 6 & $20 \%$ & Cukup Aktif \\
\hline 4. & $0-54$ & 3 & $10 \%$ & Tidak Aktif \\
\hline \multicolumn{2}{|r|}{ Total } & $\mathbf{3 0}$ & $\mathbf{1 0 0} \%$ & \\
\hline
\end{tabular}


Setelah dilakukan siklus II terlihat bahwa terjadi peningkatan yang baik terhadap aktivitas belajar siswa. Di mana dari 30 siswa memperoleh kategori tidak aktif sebanyak 3 siswa (10\%) , kategori cukup aktif 6 siswa (20\%), kategori aktif 9 siswa (30\%), dan kategori sangat aktif 12 siswa $(40 \%)$, dan telah terjadi peningkatan aktivitas belajar siswa secara keseluruhan dengan ratarata perolehan nilai aktivitas sebesar 69 masuk dalam kategori aktif.
Setelah proses pembelajaran selesai dilaksanakan maka dilakukan perhitungan terhadap hasil belajar yang diperoleh siswa. Pembagian kelompok yang heterogen berdampak pada peningkatan hasil belajar siswa. Untuk perhitungan hasil belajar siswa disajikan pada tabel berikut ini.

Tabel 9 Perolehan Nilai Hasil Belajar Siswa pada Siklus II

\begin{tabular}{|c|c|c|c|c|}
\hline No. & Interval Kelas & Frekuensi Absolut (Fo) & Frekuensi Relatif (Fr) & Keterangan \\
\hline 1. & $90-100$ & 5 & $16,67 \%$ & Sangat Kompeten \\
\hline 2. & $80-89$ & 15 & $50 \%$ & Kompeten \\
\hline 3. & $70-79$ & 6 & $20 \%$ & Cukup Kompeten \\
\hline 4. & $0-69$ & 4 & $13,33 \%$ & Tidak Kompeten \\
\hline \multicolumn{2}{r|}{ Total } & $\mathbf{3 0}$ & $\mathbf{1 0 0} \%$ & \\
\hline
\end{tabular}

Setelah diterapkan strategi pembelajaran Problem Based Learning pada siklus II, maka diperoleh nilai hasil belajar siswa dengan kategori tidak kompeten sebanyak 4 siswa $(13,33 \%)$, kategori cukup kompeten 6 siswa (20\%), kategori kompeten 15 siswa (50\%), dan kategori sangat kompeten 5 siswa (16,67\%). Telah terjadi peningkatan hasil belajar siswa yang mana telah tercapainya persentase belajar klasikal $(\geq 85 \%)$ yaitu sebesar $86,67 \%$ untuk persentase siswa yang tuntas dengan perolehan nilai rata-rata 80,57 .

Sesuai dengan data tersebut maka penerapan strategi pembelajaran Problem Based Learning dapat meningkatkan aktivitas dan hasil belajar Kewirausahaan.

\section{Tahap Refleksi (Reflection)}

Berdasarkan data pengamatan di atas hasil yang diperoleh selama siklus II ini yaitu adanya peningkatan aktivitas dan hasil belajar siswa selama proses pembelajaran. Hal ini disebabkan karena adanya perbaikan dalam mengatasi kelemahan yang terjadi pada siklus sebelumnya. Pembagian kelompok yang dilakukan secara heterogen berpengaruh dalam meningkatkan aktivitas dan hasil belajar siswa.

Peningkatan ini membuktikan bahwa siklus selanjutnya tidak perlu dilakukan lagi.

Untuk menguji hipotesis dalam penelitian ini, digunakan teknik analisa statistik deskriptif yaitu mencari nilai rata-rata dan presentase keberhasilan belajar.

Hipotesis yang pertama mengatakan dapat meningkatkan aktivitas siswa dalam pembelajaran. Dari pengamatan keaktifan siswa pada siklus I dengan 5 aspek yang dinilai kepada 30 siswa, diperoleh nilai rata-rata sebesar 63 masuk ke dalam kategori cukup, di mana siswa yang memperoleh kategori tidak aktif sebanyak 9 siswa (30\%), kategori cukup aktif 5 siswa $(16,67 \%)$, kategori aktif 10 siswa $(33,33 \%)$ dan untuk kategori sangat aktif 6 siswa (20\%) . Aktivitas siswa dapat dikatakan masih rendah dengan rata-rata kategori cukup, sehingga dilanjutkan ke siklus II untuk meningkatkan aktivitas belajar siswa. Setelah dilakukan pengamatan pada siklus II terjadi peningkatan yang baik terhadap aktivitas belajar siswa, di mana dari 30 siswa diperoleh nilai rata-rata sebesar 69 dengan kategori aktif, di mana siswa dengan kategori tidak aktif sebanyak 3 siswa (10\%), kategori cukup aktif 6 siswa (20\%), kategori aktif 9 siswa (30\%), dan kategori sangat aktif 12 siswa (40\%), maka dengan menerapkan strategi pembelajaran Problem Based Learning dapat meningkatkan aktivitas siswa dalam pembelajaran Kewirausahaan.

Hipotesis yang kedua mengatakan dapat meningkatkan hasil belajar Kewirausahaan.Dari pembahasan siklus I tentang hasil belajar Kewirausahaan dari 30 siswa diketahui nilai hasil 


\section{Penerapan Strategi Pembelajaran Problem Based Learning Untuk Meningkatkan Aktivitas dan Hasil Belajar Mata Diklat Kewirausahaan Siswa Kelas XI SMK Negeri 1 Lubuk Pakam}

belajar siswa dengan kategori tidak kompeten sebanyak 9 siswa $(30 \%)$, kategori cukup kompeten 8 siswa $(26,67 \%)$, kategori kompeten 12 siswa (40\%), sedangkan kategori sangat kompeten dicapai oleh 1 siswa saja $(3,33 \%)$. Diperoleh persentase ketuntasan klasikal $70 \%$ dengan perolehan nilai rata-rata 75,33 . Sesuai dengan data tersebut maka hasil belajar siswa dapat dikatakan belum berhasil, karena ketuntasan hasil belajar klasikal belum tercapai. Sehingga perlu dilakukan siklus II dengan menerapkan strategi pembelajaran Problem Based Learning untuk dapat meningkatkan hasil belajar Kewirausahaan siswa. Setelah dilakukan pengamatan pada siklus II diperoleh nilai hasil belajar siswa dengan kategori tidak kompeten sebanyak 4 siswa $(13,33 \%)$, kategori cukup kompeten 6 siswa (20\%), kategori kompeten 15 siswa $(50 \%)$, dan kategori sangat kompeten 5 siswa $(16,67 \%)$.

Telah terjadi peningkatan hasil belajar siswa yang mana telah tercapainya persentase belajar klasikal $(\geq 85 \%)$ yaitu sebesar $86,67 \%$ untuk persentase ketuntasan klasikal dengan perolehan nilai rata-rata 80,57. Karena persentase ketuntasan hasil belajar Kewirausahaan sudah mengalami peningkatan, maka strategi pembelajaran Problem Based Learning dapat meningkatkan hasil belajar Kewirausahaan.

\section{Kesimpulan}

Dari hasil analisis data dan pembahasan maka dapat diambil kesimpulan dari penelitian, yaitu : (1)Penerapan strategi pembelajaran Problem Based Learning dapat meningkatkan aktivitas belajar siswa pada mata pelajaran Kewirausahaan. Hal ini dapat dilihat dari nilai rata-rata siswa pada siklus I dengan nilai 63 masuk ke dalam kategori penilaian cukup, mengalami peningkatan pada siklus II yaitu dengan nilai rata-rata siswa 69 masuk ke dalam kategori penilaian aktif; (2) Ketuntasan hasil belajar siswa secara klasikal setelah dilakukan penerapan strategi pembelajaran Problem Based Learning mengalami peningkatan, yaitu dari siklus I dengan persentase ketuntasan klasikal $70 \%$ dengan nilai rata-rata 75,33 meningkat menjadi $86,67 \%$ dengan nilai rata-rata 80,57 pada siklus II. Oleh karena itu, penerapan strategi pembelajaran Problem Based Learning dapat meningkatkan hasil belajar siswa pada mata pelajaran
Kewirausahaan kelas XI Program Keahlian Teknik Gambar Bangunan SMK Negeri 1 Lubuk Pakam Tahun Ajaran 2014/2015.

\section{Daftar Pustaka}

Aqib, Z. 2009. Penelitian Tindakan Kelas Untuk Guru. Jakarta: Yrama Widya.

Arikunto, dkk. 2009. Penelitian Tindakan Kelas. Jakarta: Bumi Aksara.।

Arikunto, Suharsimi. 2009. Dasar-dasar Evaluasi Pendidikan. Jakarta: Bumi Aksara.

Djamarah dan Zain. 2008. Strategi Belajar Mengajar. Jakarta: Rineka Cipta.

Rusman. 2010. Model-Model Pembelajaran Mengembangkan Profesional Guru. Jakarta: Rajawali Pers.

Sanjaya, Wina. 2011. Strategi Pembelajaran Berorientasi Standar Proses Pendidikan. Jakarta: Kencana.

Sardiman. 2011. Interaksi dan Motivasi Belajar Mengajar.Jakarta :Rajawali Pers.

Siskandar. 2009. “Upaya Peningkatan Aktivitas Dan Hasil Belajar Melalui Model Pembelajaran Kooperative Pada Siswa SLTP Negeri Tanggerang". Jurnal Ilmu Pendidikan Volume 45 Edisi 01. Halaman 179. Padang: UniversitasNegeri Padang Press.

Slameto. 2010. Belajar \& Faktor-faktor Yang Mempengaruhinya. Jakarta: Rineke Cipta.

Suryana. 2006. Kewirausahaan. Jakarta: Salemba Empat

Trianto. 2011. MendesainModel Pembelajaran Inovatif-Progresif; Konsep, Landasan dan Implementasinya Pada Kurikulum Tingkat Satuan Pendidikan (KTSP). Jakarta : Kencana Prenada Media Group 